\title{
Intervensi Non Farmakologi untuk Meningkatkan Kualitas Tidur Postpartum: Kajian Literatur
}

\author{
Ratrika Sari $^{1}$, Anggorowati ${ }^{1 *}$ \\ ${ }^{1}$ Departemen Ilmu Keperawatan Fakultas Kedokteran Universitas Diponegoro, Semarang, Indonesia \\ anggorowati@fk.undip.ac.id
}

\begin{abstract}
Introduction: Post-partum mothers experience an inadequate sleep quality, either because of new roles or changes during postpartum. The use of drugs in the postpartum period requires consideration because it is risky for both mother and baby, so non-pharmacological interventions are safer alternative choices. During the postpartum period, the mother also carries out her own care so that non-pharmacological interventions are needed because they can be doing by self. This literature review aims to know the types of non-pharmacological interventions to improve the sleep quality of postpartum mothers.

Methods: This literature review search uses the database of Science Direct, PubMed, Google Scholar, EBSCO using the keywords "sleep quality, postpartum, intervention, nonpharmacology". The review involves 12 articles meeting the inclusion criteria.

Results: The results of review founded some interventions including back massage, foot reflexology, auricular acupressure, pilates exercise, gymnastic aerobic, chamomile tea, lavender tea, orange peel essential oil, lavender aromatherapy, lavender cream, are significant nonpharmacological interventions to improving sleep quality in postpartum.

Conclusion: The most improvement in sleep quality with foot reflexology so this intervention can be an option in nursing interventions in postpartum mother who experience sleep disorder.
\end{abstract}

Keywords: Intervention Non Pharmacology, Sleep Quality, Postpartum.

\begin{abstract}
Abstrak
Pendahuluan: Ibu post-partum mengalami penurunan kualitas tidur baik karena peran baru atau perubahan selama post-partum. Penggunaan obat-obatan pada periode postpartum membutuhkan pertimbangan karena berisiko pada ibu dan bayi, maka intervensi non farmakologi adalah pilihan alternatif yang lebih aman. Selama periode postpartum ibu juga melakukan perawatan sendiri sehingga diperlukan intervensi non farmakologi karena dapat dilakukan secara mandiri. Literature review ini bertujuan untuk mengetahui jenis intervensi non farmakologi untuk peningkatkan kualitas tidur ibu postpartum.

Metode: Pencarian literature review ini menggunakan database Science Direct, PubMed, google scholar, EBSCO dengan menggunakan kata kunci "sleep quality, postpartum, intervension, non pharmacology". Hasil pencarian diperoleh sebanyak dua belas jurnal yang sesuai dengan kriteria inklusi.

Hasil: Hasil review didapatkan beberapa intervensi yaitu back massage, refleksologi kaki, akupresur auricularis, latihan pilates, senam aerobik, teh chamomile, teh lavender, minyak esensial kulit jeruk, aromaterapi lavender, krim lavender adalah intervensi non farmakologi yang signifikan dapat meningkatkan kualitas tidur postpartum.
\end{abstract}


Kesimpulan: Peningkatan kualitas tidur paling banyak dengan intervensi refleksologi kaki sehingga intervensi ini dapat menjadi pilihan dalam intervensi keperawatan pada ibu postpartum yang mengalami gangguan tidur.

Kata Kunci: Intervensi Non Farmakologi, Kualitas Tidur, Postpartum.

\section{PENDAHULUAN}

Pola tidur ibu post-partum sebagian besar terganggu. Gangguan tidur adalah kelainan yang bisa menyebabkan masalah pada pola tidur, baik karena tidak bisa tertidur, sering terbangun pada malam hari, atau ketidakmampuan untuk kembali tidur setelah terbangun. Penyebab ibu postpartum yang mengalami gangguan tidur diantaranya adalah kelelahan fisik karena aktivitas mengasuh bayi, menyusui, memandikan bayi, menimang bayi setiap saat dapat menyebabkan istirahat ibu kurang sehingga tidur/istirahat ibu menjadi terganggu. Faktor lain yaitu nyeri jahitan perineum, rasa tidak nyaman pada kandung kemih serta gangguan dari tangisan dari bayi. Masalah yang terjadi ketika seseorang mengalami gangguan tidur yaitu akan mengalami penurunan kualitas tidur (Mansur \& Temu, 2014; Sulistyawati, 2009)

Hasil studi terkait gangguan tidur dan kualitas tidur ibu postpartum menunjukkan dari total keseluruhan $100 \%$ ibu postpartum yang mengalami gangguan tidur ringan sebanyak $45,16 \%$, gangguan tidur sedang sebanyak $29,03 \%$ dan yang mengalami gangguan tidur berat sebanyak 25,81\% (Hasna, Murwati, \& Susilowati, 2018). Rata-rata tingkat kualitas tidur ibu postpartum berada dalam kategori buruk, yakni sebanyak $37,8 \%$ dari total keseluruhan subjek (Harahap \& Adiyanti, 2017). Delapan puluh persen ibu postpartum mengeluhkan mengenai masalah tidurnya, keluhan yang dilaporkan diantaranya adalah sulit untuk memulai tidur, sering terbangun pada malam hari, tidak merasa segar saat bangun, lamanya tidur hanya 5-6 jam, merasa sangat kelelahan (Puspitasari, 2015).

Gangguan tidur pada post-partum dapat berkontribusi dalam peningkatan stress ibu dan lebih rentan terhadap suasana hati. Pola tidur ibu mengalami gangguan dan menjadi lebih sering terbangun karena bayinya. Depresi postpartum, mood seorang ibu berpengaruh juga terhadap kualitas tidur pada ibu postpartum (Bei, Coo, \& Trinder, 2014).

Pemenuhan kebutuhan istirahat dan tidur pada masa postpartum sangat dibutuhkan, penting bagi ibu yang sedang menyusui dan ibu dalam masa pemulihan setelah hamil dan melahirkan. Kebutuhan istirahat bagi ibu menyusui minimal 8 jam sehari. Kebutuhan tersebut sering tidak terpenuhi. Dampak dari kurangnya istirahat dan tidur pada ibu postpartum yaitu suplai ASI menjadi berkurang, proses involusi uterus menjadi lambat, dan menyebabkan ketidakmampuan merawat bayi (Sulistyawati, 2009).

Peningkatan pemenuhan kebutuhan istirahat tidur pada ibu postpartum dapat dilakukan secara farmakologi dan non farmakologi. Secara farmakologi dapat dengan memberikan obat-obatan golongan benzodiazepine, non-benzodiazepine dan miscellaneous sleep promoting agent. Penatalaksanaan secara farmakologi dapat memberikan risiko pada ibu postpartum. Efek samping dari obat tidur termasuk mengantuk, pusing, depresi dan mual dan di samping itu, obat ini dapat dengan mudah menyebabkan ketergantungan dan kecanduan (Lemmer, 2007). Obat tidur tidak disarankan untuk diminum saat 
menyusui karena dapat menyebabkan masalah pada bayi dan dapat berkontribusi pada masalah jangka panjang. Penggunaan obat-obatan pada periode postpartum membutuhkan pertimbangan yang cermat antara risiko pada ibu dan bayi akibat pajanan pada ASI, sehingga penatalaksanaan secara non farmakologi adalah pilihan alternatif yang lebih aman (Ods, London, \& Ladewig, 2000).

Intervensi non farmakologi merupakan intervensi mandiri perawat. Namun demikian telaah intervensi nonfarmakologi untuk peningkatan kualitas pada ibu post-partum tidur belum diketahui. Tujuan studi mengekplorasi intervensi non farmakologi untuk meningkatkan kualitas tidur ibu postpartum melalui kajian literatur.

\section{METODE}

Metode penelitian ini adalah kajian literatur, menggunakan database online dalam pencarian literature yaitu Sciencedirect, Google Scholar, PubMed, EBSCO. Kata kunci yang digunakan yaitu intervention, non pharmacology, sleep quality, postpartum. Artikel yang digunakan dengan kriteria inklusi yaitu artikel yang terbit sepuluh tahun terakhir, dalam bahasa Inggris maupun bahasa Indonesia, mendukung pernyataan tujuan penelitian, berfokus pada intervensi non farmakologi untuk tidur ibu post-partum, tidak memerlukan dana untuk diakses.

\section{HASIL}

Artikel yang diperoleh dari hasil pencarian berdasarkan kriteria inklusi didapatkan sebanyak dua belas artikel yang akan dianalisis menggunakan tabel matriks sintesis. Tabel matrik sintesis dalam tabel 1.

Tabel 1 menunjukkan bahwa intervensi nonfarmakologi terdiri dari pijat, olahraga, minuman herbal, aromaterapi dan krim. Pijat terdiri dari intervensi back massage, refleksologi kaki, refleksologi kaki dan back massage dan acupressure auricularis. Intervensi olah raga terdiri dari latihan Pilates dan senam aerobik. Minuman herbal terdapat beberapa intervensi yaitu teh chamomile, teh lavender, minyak esensial kulit jeruk. Intervensi aromaterapi dan krim yang digunakan yaitu dengan lavender.

\section{PEMBAHASAN}

Pemenuhan kebutuhan tidur penting untuk pemulihan paska melahirkan. Intervensi non farmakologis untuk meningkatkan kualitas tidur postpartum dikategorikan menjadi lima intervensi.

\section{Pijat}

Intervensi pijat untuk meningkatkan kualitas tidur postpartum diantaranya back massage (pijat punggung), refleksologi kaki, dan acupressure auricularis. Hasil studi telah menunjukkan kualitas tidur yang buruk pada postpartum dapat ditingkatkan melalui pijat punggung hasil ini konsisten dengan penelitian pijat sebelumnya, bahwa pijatan dapat secara efektif meningkatkan tidur pada wanita. Melalui pijatan, dapat memberikan rangsangan aktivasi sirkulasi sistem saraf otonom, makan jaringan ikat dan otot lebih rileks. Penelitian terkait kualitas tidur telah memberikan bukti bahwa terapi pijat efektif dalam mengatasi insomnia sesaat (Oliviera, Hachul, Tufik, \& Bittencourti, 2011). Penelitian lain pada lansia juga efektif dalam meningkatkan kualitas tidur (Rizkiana, 2018). Refleksologi kaki merupakan pijat refleksi untuk meningkat kualitas tidur postpartum. Refleksologi didasarkan pada prinsip bahwa terdapat titik di area kaki yang terhubung ke bagian tubuh atau organ yang lain melalui sistem saraf, apabila dilakukan pemijatan di titik 
tersebut akan merangsang pergerakan energi disepanjang saluran saraf dan membantu mengembalikan homeostasis atau keseimbangan energi pada tubuh (Hendro \& Ariyani, 2015).

Jenis pijat yang juga dapat meningkatkan kualitas tidur adalah akupresur aurikularis dan dinyatakan bahwa titik Shenmen dapat mengontrol tidur. Konsisten dengan penelitian sebelumnya bahwa akupresur dapat memberikan pengaruh yang signifikan terhadap peningkatan kualitas tidur lansia. Mekanisme akupresur dapat meningkatkan kualitas tidur yaitu penekanan pada titik akupresur seperti pada titik Shenmen akan menstimulus pengeluaran serotonin. Serotonin berperan sebagai neurotransmiter yang membawa sinyal menuju otak untuk memproduksi hormon melatonin. Hormon melatonin mempengaruhi otak dalam pengaturan ritme sirkadian sehingga terjadi penurunan sleep latency, nocturnal awakening, dan peningkatan total sleep time dan kualitas tidur (Iswari \& Wahyuni, 2013).

Back massage memiliki efek peningkatan kulaitas tidur. Efek peningkatan kualitas tidur paling tinggi adalah refleksologi kaki dan paling rendah adalah akupresur. Dari semua intervensi pijat semua diberikan pada periode rentan gangguan tidur postpartum. Intervensi pijat ini dilakukannya oleh ahli terapi massage hal ini mungkin dapat mempengaruhi minat ibu untuk karena ketidaktersediaannya ahli terapi massage atau pertimbangan lainya sehingga perlu edukasi massage untuk ibu postpartum dan keluarganya supaya ibu dapat melakukannya sendiri di rumah.

\section{Olahraga}

Kualitas tidur postpartum dapat ditingkatkan melalui latihan pilates dan senam aerobik. Latihan pilates selama 30 menit sedangkan senam aerobik setidaknya tiga kali (15 menit per sesi) dilakukan di rumah. Senam dilakukan pada enam minggu setelah melahirkan. Beberapa ahli menyarankan sebaiknya menunggu enam minggu untuk melakukan olahraga, sementara juga ada yang mengatakan dapat dilakukan segera, perempuan yang cukup baik kondisinya dan mampu mungkin bisa melakukan olahraga segera namun dengan intensitas ringan. Namun sebaliknya wanita yang lama dalam pemulihan, mungkin memerlukan 6 minggu penuh istirahat sebelum melakukan olahraga. Sehingga direkomendasikan beristirahat dan memulihkan diri dahulu sebelum melakukan olahraga. Latihan minimal selama 15 menit dapat meningkatkan kekuatan otot, memperkuat otot-otot perut, sehingga kesehatan ibu akan tetap terjaga dan mempermudah ibu dalam merawat bayinya (Winarni,2010).

Olahraga teratur meningkatkan fungsi kekebalan dan meningkatkan produksi zat antioksidan dalam tubuh, dan akan membantu tidur lebih nyenyak di malam hari. Pilates merupakan salah satu olahraga yang disarankan untuk ibu postpartum karena dapat memperkuat dan meningkatkan fleksibilitas otot (Winarni, 2010).

Olahraga dapat dilakukan sendiri dirumah. Intervensi ini membutuhakan ketelatenan. Senam aerobik waktu intervensinya lama namun hasilnya rendah, sedangkan pilates dilakukan lebih awal, lebih singkat dan hasilnya lebih tinggi. Perlu diperhatikan juga bahwa energi yang lebih dibutuhkan dalam melakukan intervensi ini, sehingga baru setelah pemulihan ibu dapat melakukan olahraga. 


\section{Minuman Herbal}

Tanaman yang digunakan sebagai bahan dasar minuman herbal memiliki kandungan yang memberikan efek sedatif sehingga dapat meningkatkan kualitas tidur. Minuman yang digunakan diantaranya teh chamomile, teh lavender, dan minyak esensial kulit jeruk. Komponen utama yang terkandung dalam bunga chamomile flavonoid, apigenin adalah senyawa yang paling banyak bermanfaat (Srivastava, Shankar, \& Gupta, 2010). Hasil penelitian sebelumnya terkait penggunaan teh chamomile hangat pada lansia menyatakan mampu membuat tidur lebih nyenyak karena zat kimia apigenin yang terkandung oleh chamomile akan terikat oleh reseptor benzodiazepin di sistem saraf pusat kemudian bekerja dengan cara merangsang otak sehingga timbul rangsangan rasa kantuk (Widodo, Haryanto, \& Bakar, 2010). Kandungan flavonoid dari setiap tanaman yang digunakan diketahui mampu memberikan efek sedatif yang bermafaat untuk mengatasi tidur. Menurut penelitian yang dilakukan sebelumnya, linalool ditemukan di minyak atsiri kulit jeruk melalui interaksi dengan reseptor GABA, bertindak sebagai obat penenang, sedangkan linalyl asetat memiliki efek narkotika (Qiao et al., 2008; Ozgoli, Shahveh, Esmaiellis, \& Nassiri, 2011).

Ketiga minuman herbal ini dapat menjadi pilihan untuk dilakukan pada periode rentan gangguan tidur postpartum atau sesudah periode rentan, karena waktu pemberian dari ketiga intervensi tersebut berbeda. Intervensi teh chamomile dan minyak esensial kulit jeruk terbukti mampu meningkatkan kualitas tidur postpartum selain pada ibu dengan persalinan pervaginam maupun caesar.

\section{Aromaterapi}

Hasil dari pemberian aromaterapi lavender efektif untuk meningkatkan kualitas tidur postpartum. Aroma terapi lavender efektif meningkatkan kualitas tidur postpartum (Laura, 2015). Aroma lavender juga dapat menurunkan risiko insomnia (Ramadhian \& Zettira, 2017).

Kandungan bunga lavender yaitu linanool berfungsi sebagai efek sedatif sehingga aroma yang tercium menstimulasi reseptor silia saraf olfactorius kemudian aroma tersebut diteruskan ke otak diteruma sebagi informasi berupa aroma, selanjutnya melalui hipotalamus sampai ke nukleus raphe. Jika nukleus raphe terstimulasi akan terjadi pelepasan serotonin yang mengatur permulaan untuk tidur (Buckle, 2015; Chamine \& Oken, 2014).

Aromaterapi lavender memberikan efek yang rendah terhadap peningkatan kualitas tidur postpartum dibandingkan intervensi yang lain. Lamanya intervensi yaitu delapan minggu terbilang cukup lama, namun penggunaannya bisa langsung sejak awal postpartum, pengaplikasiannya mudah dan bahan yang digunakan juga mudah untuk didapatkan.

\section{Krim}

Uji coba penggabungan 2 macam intervensi mengahsilkan peningkatan kualitas tidur pada postpartum, yaitu pemberian krim lavender dan merendam kaki (footbath), krim topikal digosokkan pada kaki. Kandungan bahan krim dari lavender dapat diserap melalui kulit sehingga dengan adanya penyerapan kulit lavender dapat menghilangkan rasa sakit, edema, meningkatkan sirkulasi darah pada anggota badan, relaksasi, dan menciptakan perasaan yang menyenangkan. Efek relaksasi ini akan membuat tidur ibu lebih nyenyak (Poerwadi, 2006). 
Intervensi gabungan dengan ditambah footbath dengan merendam kaki setelah menggunakan krim. Hasil penelitian sebelumnya rendam kaki di air hangat juga mampu meningkatkan kualitas tidur juga pada usia lanjut (Ningtyas, 2014). Krim lavender hanya dilakukan dengan mengoleskan krim pada kaki, namun setelah enam minggu intervensi efek yang ternilai tidak terlalu tinggi jika dibandingkan dengan intervensi yang lain. Perlu diperhatikan sebelum menggunakan kemungkinan terjadinya alergi atau efek samping lain yang ditimbulkan akibat kulit sensitif karena jenis kulit setiap orang berbeda-beda.

\section{KESIMPULAN DAN SARAN}

Intervensi non farmakologi efektif meningkatkan kualitas tidur pada ibu postpartum diantarnya yaitu back massage, refleksologi kaki, akupresure auricularis, latihan pilates, senam aerobik, teh chamomile, teh lavender, minyak esensial kulit jeruk, aromaterapi lavender, krim lavender. Jika dilihat dari hasil penurunan skor kualitas tidur, peningkatan kualitas tidur paling banyak dihasilkan oleh intervensi refleksologi kaki.

Hasil penelitian ini harapannya dapat dijadikan jembatan dalam pengembangan penelitian selanjutnya, dijadikan sebagai sumber referensi serta acauan dalam pemberian intervensi keperawatan untuk meningkatkan kualitas tidur pada ibu postpartum.

\section{DAFTAR PUSTAKA}

Ashfar, M. K., Moghadam, B. Z., Bekhradi, Z. T. R., \& Mokhtari, A. M. P. (2015). Lavender fragrance essential oil and the quality of sleep in postpartum women. Iranian Red Crescent Medical Journal, 17(4): 1-7.
Ashrafinia, F., Mirmohammadali, M., Rajabi, H., Kazemnejad, A., Haghighi, K. S., \& Amelvalizadeh, M. (2013). The effects of Pilates exercise on sleep quality in postpartum women. Journal of Bodywork \& Movement Therapies, 18(12): 190-199.

Bei, B., Coo, S., \& Trinder, J. (2014). Sleep and mood during pregnancy and the postpartum period. Sleep Medicine Clinics, 10(1), 25-33. doi: 10.1016/J.Jsmsc.2014.11.011

Buckle, J. (2015). Clinical aromatherapy essential oil: Healthcare. Ed. 3.Philadelphia: Churchill Livingstone

Chamine, I., \& Oken, B. S. (2014). Aroma effect on physiologic and cognitive function following acute stress: A mechanism investigation. Journal Alternative Complement Medicine, 22(9), 713-21.

Chang, S. M., \& Chen, C. H. (2016). Effects of an intervention with drinking chamomile tea on sleep quality and depression in sleep disturbed postnatal women: a randomized controlled trial. Journal of Advanced Nursing, 72(2), 306-315.

Chen, S. L., \& Chen, C. H. (2015). Effects of lavender tea on fatigue,depression, and maternal-infant attachment in sleep-disturbed postnatal women. Worldviews on Evidence-Based Nursing, 12(6), 370-379.

Fatemeh Effati-Daryani, F., Sakineh Mohammad-Alizadeh-Charandabi, S., Mirghafourvand, M., Taghizadeh, M., Bekhradi, R., \& Zarei, S. (2018). Effect of lavender cream with or without footbath on sleep quality and fatigue in pregnancy and postpartum: 
A randomized controlled trial. Women \& Health, 58(10), 1179-91. Doi: 10.1080/03630242.2017.1414101

Harahap, W., \& Adiyanti M. G. (2017). Kualitas tidur dan pola tidur sebagai prediposisi postpartum blues pada primipara. Jurnal Kesehatan Reproduksi, 4(1), 50-55.

Hasna, A. N., Murwati, \& Susilowati, D. (2018). Hubungan gangguan tidur ibu nifas dengan kejadian postpartum blues di wilayah kerja Puskesmas Karangmalang Sragen. Surakarta: Politeknik Kesehatan Surakarta Jurusan Kebidanan.

Hendro \& Ariyani, Y. (2015). Ilmu pijat pengobatan refleksi relaksasi. Jakarta: Direktorat Pembinaan Kursus dan Pelatihan.

Ibrahim, A., El-Sheikh, M. A., \& Ahmed A. (2017). Effect of back massage on sleep duration among postpartum women. Egyptian Journal of Health Care, 8(1), 377-387.

Iswari, N. L. P. A. M., \& Wahyuni, A. A. S. (2013). Melatonin dan melatonin receptor gonist sebagai penanganan insomnia primer kronis. Jurnal Medika Udayana, 2(4), 1-14.

Ko, Y., \& Lee, H. J. (2014). Randomised controlled trial of the effectiveness of using back massage to improve sleep quality among Taiwanese insomnia postpartum women. Midwifery, 30(1), 60-64. doi: 10.1016/j.midw.2012.11.005

Ko, Y. L., Lin, S. C., \& Lin, P. C. (2016). Effect of auricular acupressure for postpartum insomnia: an uncontrolled clinical trial. Journal of Clinical
Nursing, $\quad 25(3-4), \quad 332-339 . \quad$ doi: 10.1111/jocn.13053

Laura, D. (2015). Efektifitas aromaterapi lavender terhadap kualitas tidur ibu postpartum. Jurnal Online Mahasiswa, 2(2), 1024-31.

Lemmer. (2007). The sleep-wake cycle and sleeping pills. Physiology \& Behavior, 90(2-3), 285-293. doi: 10.1016/j.physbeh.2006.09.006

Li, C. Y., Chen, S. C., Li, C. Y., Gau, M. L. \& Huang, C. M. (2011). Randomised controlled trial of the effectiveness of using foot reflexology to improve quality of sleep amongst taiwanese postpartum women. Midwifery, 27(2), 181-186. doi: 10.1016/j.midw.2009.04.005

Manjuri, A. E., \& Latheef, F. (2016). Effectivenes of foot reflekxology and back massage in improving the quality of sleep among post caesarean mothers. International of Research in Ayurveda and Pharmacy. 7(5),103108.

Mansur, H., \& Temu, B. (2014). Psikologi ibu dan anak. Jakarta: Salemba Medika.

Mirghafourvand, M., Charandabi, S. M., Hakimi, S., Khodaie, L., Galeshi, M. (2015). Effect of orange peel essential oil on postpartum sleep quality: A randomized controlled clinical trial. European Journal of Integrative Medicine, 8(1): 62-66.

Ningtyas, A. P. (2014). Pengaruh rendam kaki dengan air hangat terhadap kualitas tidur usia lanjut di Dusun Mangiran Trimurti Srandakan Bantul. 
Yogyakarta: Sekolah Tinggi Ilmu Kesehatan 'Aisyah Yogyakarta.

Oliviera, D., Hachul, H., Tufik, S., \& Bittencourti, L. (2011). Effect of massage in postmenopausal women with insomnia - A pilot study. Clinics, 66(2), 343-346. doi: 10.1590/S180759322011000200026

Ozgoli, G., Shahveh, M., Esmaiellis, S, Nassiri, N.( 2011). Essential oil of citrus sinensis for the treatment of premenstrual syndrome: A randomized double-blind placebo-controlled trial. Journal Reproduction Infertil, 12(2), 123-129.

Poerwadi, R. (2006). Aromaterapi sahabat calon ibu. Jakarta: Dian Rakyat.

Puspitasari, S. R. (2015). Latihan relaksasi otot progesif dalam upaya meningkatkan kualitas tidur pada ibu postpartum di Wilayah Kerja Puskesmas Kandat-Kediri. Surabaya: Universitas Airlangga.

Qiao, Y., Xie, B. J., Zhang, Y., Fan, G., \& Yao, X. L. (2008). Characterization of aroma active compounds in fruit juice and peel oil of Jinchen sweet orange fruit (Citrus sinensis (L.) Osbeck) by GC-MS and GC-O. Molecules, 13(6), 1333-44. doi: 10.3390/molecules13061333

Ramadhian, M.R., \& Zettira, O. Z. (2017). Aromaterapi bunga lavender (Lavandula angustifolia) dalam menurunkan risiko insomnia. Majority, 6(2), 60-63.

Rizkiana, J. (2018). Pengaruh terapi massage punggung terhadap kualitas tidur lansia di Balai Pelayanan Sosial Tresna Werdha Unit Budi Luhur
Kasongan Bantul Yogyakarta. Yogyakarta: Universitas Aisyah Yogyakarta.

Ods, S. B., London, M. L., \& Ladewig., P. A. W. (2000). Maternal-newborn nursing: A family and community based approach. New Jersey: Prentice-Hall Inc.

Srivastava, J. K., Shankar, E., \& Gupta, S. (2010). Chamomile: A herbal medicine of the past with bright future. Molecular Medicine Reports, 3(6), 895-901.

Sulistyawati, A. (2009). Buku ajar asuhan kebidanan pada ibu nifas. Yogyakarta: Andi Offset.

Widodo, D. S., Haryanto, J., \& Bakar, A. (2010). Studi komparasi minum susu hangat dan teh chamomile hangat terhadap pemenuhan kebutuhan tidur lansia. Indonesian Journal of Community Health Nursing, 3(1),117124. doi: 10.20473/ijchn.v3is.12217

Winarni, S. (2010). Olahraga pasca melahirkan. Medikora, 6 (2), 19-28.

Yang, C. L., \& Chen, C. H. (2018). Effectiveness of aerobic gymnastic exercise on stress, fatigue, and sleep quality during postpartum: A pilot randomized controlled trial. International Journal of Nursing Studies, $\quad 77$ : 1-7. doi: 10.1016/j.ijnurstu.2017.09.009 
Tabel 1. Matrik Sintesis

\begin{tabular}{|c|c|c|c|c|c|c|}
\hline Penulis/Tahun & Tujuan & Metode & Sampel & Temuan & Kesamaan & $\begin{array}{l}\text { Keunikan } \\
\end{array}$ \\
\hline $\begin{array}{l}\text { Yi-li Ko, Hsiu- } \\
\text { Jung Lee. } 2014\end{array}$ & $\begin{array}{lr}\text { Menguji } & \text { efektifitas } \\
\text { penggunaan } & \text { pijat } \\
\text { punggung } & \text { untuk } \\
\text { meningkatkan } & \text { kualitas } \\
\text { tidur wanita postpartum }\end{array}$ & $\begin{array}{l}\text { randomised } \\
\text { controlled trial }\end{array}$ & $\begin{array}{l}60 \text { wanita } \\
\text { postpartum di } \\
\text { salah satu } \\
\text { postpartum centre } \\
\text { Taiwan dengan } \\
\text { kualitas tidur yang } \\
\text { buruk }\end{array}$ & $\begin{array}{l}\text { Efek pijat punggung pada kualitas } \\
\text { tidur postpartum diukur } \\
\text { menggunakan PSQI. Pada awal } \\
\text { (pretest, post-partum hari ke 8), rata- } \\
\text { rata Skor PSQI untuk kelompok } \\
\text { intervensi adalah 9,37 Pada post- } \\
\text { partum Hari } 13 \text { postpartum skor PSQI } \\
\text { untuk telah menurun secara signifikan } \\
\text { menjadi 4,50 penurunan sebesar 4,87 }\end{array}$ & 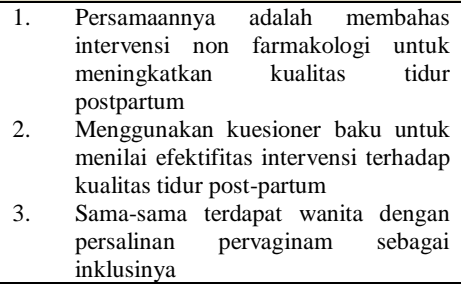 & $\begin{array}{l}\text { Penelitian ini menggunakan intervensi } \\
\text { untuk meningkatkan kualitas tidur post- } \\
\text { partum berupa back massage (pijat } \\
\text { punggung) yang dilakukan } 20 \text { menit sekali } \\
\text { tiap hari dijam yang sama selama lima hari } \\
\text { berturut-turut dari post-partum hari } 9 \\
\text { hingga 13. }\end{array}$ \\
\hline $\begin{array}{l}\text { Asmaa Ibrahim, } \\
\text { Mona A. El- } \\
\text { Sheikh, Shimaa } \\
\text { Ahmed. } 2017\end{array}$ & $\begin{array}{l}\text { Mengevaluasi efek } \\
\text { pijat punggung pada } \\
\text { durasi tidur di antara } \\
\text { wanita post-partum. }\end{array}$ & $\begin{array}{l}\text { Intervention } \\
\text { study design }\end{array}$ & $\begin{array}{l}60 \text { wanita post- } \\
\text { partum }\end{array}$ & $\begin{array}{l}\text { Ada peningkatan yang sangat } \\
\text { signifikan dalam durasi tidur pada } \\
\text { intervensi } \\
\text { kelompok pada saat awal intervensi } \\
\text { dan pada akhir waktu intervensi. } \\
\text { Selama } 8 \text { hari intervensi skor PSQI } \\
\text { menurun 10,83 }\end{array}$ & $\begin{array}{l}\text { Intervensi yang dinilai merupakan } \\
\text { intervensi non farmakologi untuk } \\
\text { tidur postpartum } \\
\text { Dinilai menggunakan kuesioner baku } \\
\text { Hanya wanita kelahiran pervaginam } \\
\text { yang dujadikan kriteria sampel }\end{array}$ & $\begin{array}{l}\text { Selain menggunakan kuesioner PSQI } \\
\text { kualitas tidur juga dinilai melalui } \\
\text { wawancara denagn 21 pertanyaan terdiri } \\
\text { dari pertanyaan terbuka dan tertutup. }\end{array}$ \\
\hline $\begin{array}{l}\text { Chia-Yen Li, } \\
\text { Su-Chiu Chen, } \\
\text { Chung-Yi Li, } \\
\text { Meei-Ling Gau, } \\
\text { Chiu-Mieh Huang. } \\
2011\end{array}$ & $\begin{array}{l}\text { Menguji efektifitas } \\
\text { penggunaan } \\
\text { refleksiologi kaki untuk } \\
\text { meningkatkan kualitas } \\
\text { tidur wanita postpartum }\end{array}$ & $\begin{array}{l}\text { Randomised } \\
\text { controlled trial }\end{array}$ & $\begin{array}{l}65 \text { wanita post- } \\
\text { partum di dua } \\
\text { post-partum } \\
\text { centre Taiavan } \\
\text { utara kualitas tidur } \\
\text { yang buruk }\end{array}$ & $\begin{array}{l}\text { Efek refleksiologi pada kualitas tidur } \\
\text { postpartum diukur menggunakan } \\
\text { PQSI. Pada awal skor PQSI rata-rata } \\
\text { untuk kelompok intervensi adalah 9,94 } \\
\text { pada hari ke-13 postpartum, skor PSQI } \\
\text { menurun 5,97 sehingga dari 9,94 } \\
\text { menjadi 3,97 }\end{array}$ & $\begin{array}{l}\text { Intervensi yang diuji juga jenis non } \\
\text { farmakologi untuk meningkatkan } \\
\text { kualitas tidur post-partum } \\
\text { Sama menggunakan kuesioner baku } \\
\text { untuk mengukur hasil intervensi } \\
\text { Kriteria inklusi sama yaitu wanita } \\
\text { dengan persalinan pervaginam }\end{array}$ & $\begin{array}{l}\text { Penggunaan refleksiologi pada kaki untuk } \\
\text { meningkatkan kualitas tidur postpartum, } \\
\text { sesi refleksiologi diberikan } 15 \text { menit pada } \\
\text { setiap kaki total } 30 \text { menit waktu terapi. }\end{array}$ \\
\hline $\begin{array}{l}\text { Manjuri. A E, } \\
\text { Fathima Latheef. } \\
2016\end{array}$ & $\begin{array}{l}\text { Mengevaluasi } \\
\text { efektivitas dari refleksi } \\
\text { kaki dan } \\
\text { pijat punggung dalam } \\
\text { meningkatkan kualitas } \\
\text { tidur wanita post } \\
\text { operasi caesar } \\
\end{array}$ & $\begin{array}{l}\text { Experimental } \\
\text { repeated } \\
\text { measures } \\
\text { design }\end{array}$ & $\begin{array}{l}120 \text { ibu post } \\
\text { caesar }\end{array}$ & $\begin{array}{l}\text { Hasil yang ditunjukkan mengalami } \\
\text { peningkatan kualitas tidur pada dua } \\
\text { kelompok intervensi. Kelompok bback } \\
\text { massage skor PSQI menurun sebanyak } \\
3,0 \text { sedangkan kelompok refleksologi } \\
\text { kaki menurun 5,0 }\end{array}$ & $\begin{array}{l}\text { Sama-sama mengevaluasi keefektifan } \\
\text { intervensi nonfarmakologi untuk tidur } \\
\text { post-partum tidur juga diukur } \\
\text { Kualitas tidur } \\
\text { menggunakan kuesioner baku }\end{array}$ & $\begin{array}{l}\text { 1. Dalam satu waktu penelitian } \\
\text { membandingkan dua jenis intervensi } \\
\text { yaitu antara back massage dan } \\
\text { refleksiologi kaki } \\
\text { 2. Hanya menilai pada postpartum } \\
\text { dengan kelahiran caesar } \text { saja }\end{array}$ \\
\hline $\begin{array}{l}\text { Yi-Li Ko, Shih- } \\
\text { Chi Lin, Pi-Chu } \\
\text { Lin. } 2016\end{array}$ & $\begin{array}{l}\text { Meneliti efek terapi } \\
\text { akupresur aurikularis } \\
\text { pada wanita postpartum } \\
\text { dengan insomnia }\end{array}$ & $\begin{array}{l}\text { One-group } \\
\text { pretest post-test } \\
\text { quasi- } \\
\text { experimen }\end{array}$ & $\begin{array}{l}30 \text { wanita post- } \\
\text { partum dengan } \\
\text { insomnia }\end{array}$ & 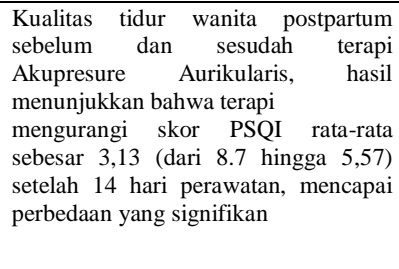 & $\begin{array}{ll}\text { 1. } & \begin{array}{l}\text { Membahas jenis intervensi non } \\
\text { farmakologi untuk meningkatkan }\end{array} \\
\text { kualitas tidur postpartum }\end{array}$ & $\begin{array}{l}\text { Bentuk intervensi yang diberikan adalah } \\
\text { terapi akupresure dengan menekan pada } \\
\text { satu titik auricular (titik Shenmen) di satu } \\
\text { telinga dengan magnet ferit selama tujuh } \\
\text { hari dan pada hari kedelapan, pindah ke } \\
\text { titik Shenmen di telinga yang lain }\end{array}$ \\
\hline $\begin{array}{l}\text { Farzaneh } \\
\text { Ashrafinia, } \\
\text { Mandana }\end{array}$ & $\begin{array}{l}\text { Mengetahui efek dari } \\
\text { program pelathan } \\
\text { Pilates terkait kualitas }\end{array}$ & $\begin{array}{l}\text { Randomized } \\
\text { controlled } \\
\text { clinical trial }\end{array}$ & $\begin{array}{lr}80 \text { wanita } & \text { post- } \\
\text { partum } & \text { secara } \\
\text { acak } & \text { dibagi } \\
\end{array}$ & $\begin{array}{l}\text { Kualitas tidur yang buruk saat awal } \\
\text { postpartum (pada } 24 \text { jam setelah } \\
\text { melahirkan) dapat ditingkatkan setelah }\end{array}$ & $\begin{array}{l}\text { Membahas } \\
\text { farmakologi untervensi } \\
\text { kualitas tidur postpartum }\end{array}$ & $\begin{array}{l}\text { 1. Intervensi berbasis rumah yaitu } \\
\text { dengan mengarahkan ibu postpartum } \\
\text { untuk melakukan latihan pilates }\end{array}$ \\
\hline
\end{tabular}




\begin{tabular}{|c|c|c|c|c|c|c|}
\hline Penulis/Tahun & Tujuan & Metode & Sampel & Temuan & Kesamaan & Keunikan \\
\hline $\begin{array}{l}\text { Mirmohammadali, } \\
\text { Hamid Rajabi, } \\
\text { Anooshirvan } \\
\text { Kazemnejad, } \\
\text { Khosro } \\
\text { SadeghniiatHaghi } \\
\text { ghi, } \\
\text { Mehrnoosh } \\
\text { Amelvalizadeh. } \\
2013\end{array}$ & $\begin{array}{l}\text { tidur pada wanita } \\
\text { primigravida } \\
\text { postpartum }\end{array}$ & & $\begin{array}{l}\text { menjadi kelompok } \\
\text { intervensi dan } \\
\text { kontrol }\end{array}$ & $\begin{array}{l}8 \text { minggu latihan Pilates, kelompok } \\
\text { intervensi memiliki } \\
\text { peningkatan yang signifikan dalam } \\
\text { kualitas tidur subjektif, latensi tidur, } \\
\text { disfungsi siang hari dan skor global } \\
\text { PSQI dari } 9,97 \text { menjadi } 5,45\end{array}$ & $\begin{array}{l}\text { Kuesioner untuk menilai hasil ukur } \\
\text { kualitas tidur juga baku yaitu PSQI } \\
\text { Wanita dengan persalinan pervaginam } \\
\text { juga dipilih sebagai kriteria inklusi }\end{array}$ & $\begin{array}{l}\text { meliputi } 13 \text { gerakan khusus post- } \\
\text { partum, untuk meningkatkan kualitas } \\
\text { tidur dan ditindaklanjuti melalui } \\
\text { telepon } \\
\text { Populasi penelitian khusus untuk } \\
\text { postpartum primigravida }\end{array}$ \\
\hline $\begin{array}{l}\text { Chiu-Ling Yang, } \\
\text { Chung-Hey Chen. } \\
2018\end{array}$ & $\begin{array}{l}\text { Uji coba } \\
\text { efek latihan aerobic } \\
\text { melalui DVD pada } \\
\text { kualitas tidur pada } \\
\text { wanita post-partum } \\
\text { Taiwan. }\end{array}$ & $\begin{array}{l}\text { Randomized } \\
\text { controlled trial } \\
\text { with } a \\
\text { prospective } \\
\text { pretest-posttest } \\
\text { experimental }\end{array}$ & $\begin{array}{l}140 \text { wanita } \\
\text { postpartum yang } \\
\text { direkrut dari klinik } \\
\text { postnatal di } \\
\text { Taiwan selatan }\end{array}$ & $\begin{array}{l}\text { Dengan uji } t \text { berpasangan hasil tes } \\
\text { menunjukkan bahwa perubahan } \\
\text { inefisiensi tidur yang berkaitan dengan } \\
\text { gejala fisik setelah } 12 \text { minggu latihan } \\
\text { senam aerobic menurun skor PSQS } \\
\text { secara signifikan pada kelompok } \\
\text { eksperimen yaitu } 21,92 \text { menjadi } 19,58\end{array}$ & $\begin{array}{ll}\text { 1. } & \begin{array}{l}\text { Menggunakan intervensi non } \\
\text { farmakologi sebagai intervensi yang } \\
\text { digunakan untuk meningkatkan }\end{array} \\
\text { kualitas tidur post-partum } \\
\text { 2. }\end{array}$ & $\begin{array}{l}\text { Penelitian ini mengembangkan latihan } \\
\text { aerobik dengan menggabungkan } \\
\text { gerakan dan musik menjadi sebuah } \\
\text { DVD yang cocok digunakan wanita } \\
\text { postpartum untuk latihan di rumah. } \\
\text { Waktu intervensi paling lama diantara } \\
\text { intervensi yang lain yaitu selama } 3 \\
\text { bulan }\end{array}$ \\
\hline $\begin{array}{l}\text { Shao-Min Chang, } \\
\text { Chung-Hey Chen. } \\
2016\end{array}$ & $\begin{array}{l}\text { Mengevaluasi efek teh } \\
\text { chamomile pada } \\
\text { kualitas tidur, wanita } \\
\text { post-partum. }\end{array}$ & $\begin{array}{l}\text { Pre-post-test } \\
\text { randomized } \\
\text { controlled trial }\end{array}$ & $\begin{array}{l}80 \text { wanita } \\
\text { postnatal Taiwan } \\
\text { dengan kualitas } \\
\text { tidur yang buruk } \\
\text { (Skala kualitas } \\
\text { tidur post-partum; } \\
\text { skor PSQS } \geq 16 \text { ) }\end{array}$ & $\begin{array}{l}\text { Efektivitas intervensi yang dilakukan } \\
\text { pada } 2 \text { dan } 4 \text { minggu pasca intervensi } \\
\text { yaitu terjadi perbedaan yang signifikan } \\
\text { pada post-test dalam tidur terkait } \\
\text { gejala-afisik PSQS subskala inefisiensi. } \\
\text { Hasil mengidentifikasi manfaat untuk } \\
\text { wanita postpartum minum the } \\
\text { chamomile Jerman untuk } 2 \text { minggu } \\
\text { termasuk peningkatan yang signifikan } \\
\text { dalam gejala fisik yang berkaitan } \\
\text { dengan inefisiensi tidur. Skor PSQS } \\
\text { telah menurun semula } 25,12 \text { menjadi } \\
20,25\end{array}$ & $\begin{array}{l}\text { 1. Pokk bahasannya adalah sama yaitu } \\
\text { intervensi non farmakologi untuk } \\
\text { meningkatkan kualitas tidur post- } \\
\text { partum } \\
\text { 2. Merupakan kuesioner baku untuk } \\
\text { menilai hasil ukur kualitas tidur } \\
\text { postpartum an digunnakan selain } \\
\text { 3. Responden yang danan } \\
\text { wanita dengan persalinan Caesar juga } \\
\text { sama-sama menggunakan kriteria } \\
\text { inklusi wanita dengan persalinan } \\
\text { pervaginam }\end{array}$ & $\begin{array}{l}\text { Intervensi untuk meningkatkan } \\
\text { kualitas tidur post-partum pada } \\
\text { penelitian ini adalah meminum 1 } \\
\text { cangkir teh chamomile } \\
\text { Kefektifan intervensi hanya dinilai } \\
\text { dengan pre dan post intervensi dan } \\
\text { tidak menggunakan placebo } \\
\text { Populasi post-partum mencakup } \\
\text { kelahiran caesar jadi tidak hanya } \\
\text { yang melahirkan pervaginam saja }\end{array}$ \\
\hline $\begin{array}{l}\text { Shu-Lan Chen, } \\
\text { Chung-Hey Chen. } \\
2015\end{array}$ & $\begin{array}{l}\text { Mengevaluasi } \\
\text { efektifitas teh lavender } \\
\text { di Taiwan } \\
\text { dalam meningkatkan } \\
\text { kualitas tidur, } \\
\text { selama periode post- } \\
\text { partum awal }\end{array}$ & $\begin{array}{l}\text { Pretest-posttest } \\
\text { randomized } \\
\text { controlled } \\
\text { group }\end{array}$ & $\begin{array}{l}80 \text { wanita post- } \\
\text { partum dengan } \\
\text { kualitas tidur yang } \\
\text { buruk (Skor PSQS } \\
\geq 16 \text { ) dan tanpa } \\
\text { riwayat alergi }\end{array}$ & $\begin{array}{l}\text { Studi ini menemukan bahwa partisipan } \\
\text { yang mengonsumsi teh lavender } \\
\text { selama 2 minggu berturut-turut } \\
\text { menunjukkan penurunan yang } \\
\text { signifikan pada postpartum dengan } \\
\text { kualitas tidur buruk. Namun, setelah } \\
\text { menghentikan intervensi ini efek } \\
\text { positif tidak bertahan cukup lama pada } \\
\text { post-test 4 minggu (10 minggu } \\
\text { postpartum). Hasil skor PSQS adalah } \\
\text { rata-rata menurun 1,56 }\end{array}$ & 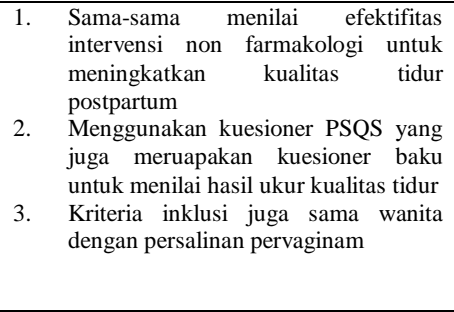 & $\begin{array}{l}\text { Pemberian intervensi dengan memberikan } \\
\text { minuman teh herbal namun sebelum } \\
\text { memiminum juga menghirup aromanya } \\
\text { karena aroma dari teh lavender juga } \\
\text { memberikan efek pada kualitas tidur post- } \\
\text { partum }\end{array}$ \\
\hline $\begin{array}{l}\text { Mojgan } \\
\text { Mirghafourvand, } \\
\text { Sakineh } \\
\text { Mohammad- } \\
\text { Alizadeh }\end{array}$ & $\begin{array}{l}\text { Penelitian ini bertujuan } \\
\text { untuk mengetahui } \\
\text { pengaruh minyak } \\
\text { esensial kulit jeruk } \\
\text { pada kualitas tidur }\end{array}$ & $\begin{array}{l}\text { Triple-blind } \\
\text { randomized } \\
\text { controlled } \\
\text { clinical trial }\end{array}$ & $\begin{array}{l}96 \text { wanita post- } \\
\text { partum yang } \\
\text { memenuhi kriteria } \\
\text { inklusi }\end{array}$ & $\begin{array}{l}\text { Peningkatan yang signifikan dalam } \\
\text { tidur kualitas diamati pada kelompok } \\
\text { yang menerima minyak esensial kulit } \\
\text { jeruk dibandingkan dengan kelompok } \\
\text { kontrol di } 8 \text { minggu setelah }\end{array}$ & $\begin{array}{l}\text { 1. Intervensi yang digunakan sama-sama } \\
\text { non farmakologi yang bertujuan untuk } \\
\text { meningkatkan kualitas tidur } \\
\text { postpartum }\end{array}$ & $\begin{array}{l}\text { Intervensi minuman berupa minyak esensial } \\
\text { kulit jeruk dilarutkan dalam air, dengan ini } \\
\text { mampu memberikan perubahan sangat } \\
\text { signifikan pada semua komponen termasuk } \\
\text { kualitas tidur subjektif, latensi tidur, durasi }\end{array}$ \\
\hline
\end{tabular}

Ratrika Sari \& Anggorowati., Intervensi Non Farmakologi untuk .... 


\begin{tabular}{|c|c|c|c|c|c|c|}
\hline Penulis/Tahun & $\begin{array}{c}\text { Tujuan } \\
\end{array}$ & Metode & Sampel & Temuan & Kesamaan & Keunikan \\
\hline $\begin{array}{l}\text { Charandabi, } \\
\text { Laleh Khodaie, } \\
\text { Mina Galeshi. } \\
2015\end{array}$ & setelah melahirkan & & & $\begin{array}{l}\text { melahirkan hasilnya yaitu skor PSQI } \\
\text { sebelum intervensi adalah } 10,4 \text { dan } \\
\text { menjadi } 4,8 \text { terhitung penurunan } \\
\text { sebesar } 5,6\end{array}$ & $\begin{array}{l}\text { menilai hasil ukur kualitas tidurnya } \\
\text { Kriteria inklusi yang digunkan yaitu } \\
\text { wanita dengan persalinan pervaginam }\end{array}$ & tidur, efisiensi tidur dan gangguan tidur \\
\hline $\begin{array}{l}\text { Mahnaz } \\
\text { Keshavarz Afshar, } \\
\text { Zahra Behboodi } \\
\text { Moghadam, Ziba } \\
\text { Taghizadeh Reza } \\
\text { Bekhradi, Ali } \\
\text { Montazeri, Pouran } \\
\text { Mokhtari. } 2015\end{array}$ & $\begin{array}{l}\text { Mengetahui pengaruh } \\
\text { aromaterapi lavender } \\
\text { terhadap kualitas tidur } \\
\text { pada wanita postpartum }\end{array}$ & $\begin{array}{l}\text { Randomized } \\
\text { clinical trial } \\
\text { with the control } \\
\text { group }\end{array}$ & $\begin{array}{l}\text { Sebanyak } 158 \text { ibu } \\
\text { di masa nifas } \\
\text { (dengan kriteria } \\
\text { inklusi tertentu) }\end{array}$ & $\begin{array}{l}\text { Setelah } 8 \text { minggu intervensi, terdapat } \\
\text { peningkatan yang signifikan muncul } \\
\text { pada kualitas tidur ibu dalam } \\
\text { kelompok intervensi. Aromaterapi } \\
\text { meningkatkan skor rata-rata kualitas } \\
\text { tidur } \\
\text { dari skor } 8,28 \text { menurun menjadi } 6,79\end{array}$ & $\begin{array}{l}\text { 1. Menilai intervensi non farmakologi } \\
\text { untuk meningkatkan kualitas tidur } \\
\text { postpartum } \\
\text { 2. Kuesionernya juga sama baku yaitu } \\
\begin{array}{l}\text { PSQI untuk mengukur hasil ukur } \\
\text { kualitas tidurnya }\end{array} \\
\text { 3. Wanita dengan persalinan pervaginam } \\
\text { juga sebagai kriteria inklusi yang } \\
\text { digunakan }\end{array}$ & $\begin{array}{ll}1 . & \begin{array}{l}\text { Prosedur intervensi pemberian } \\
\text { aromaterapi tidak langsung dihirup } \\
\text { dari wadahnya melainkan diteteskan }\end{array} \\
\text { pada bola kapas terlebih dahulu } \\
\text { 2. } \\
\text { Kriteria inklusi peserta adalah wanita } \\
\text { primipara }\end{array}$ \\
\hline $\begin{array}{l}\text { Fatemeh Effati- } \\
\text { Daryani, Sakineh } \\
\text { Mohammad- } \\
\text { Alizadeh- } \\
\text { Charandabi, } \\
\text { Mojgan } \\
\text { Mirghafourvand, } \\
\text { Mohsen } \\
\text { Taghizadeh, Reza } \\
\text { Bekhradi, } \\
\text { Somayeh Zarei. } \\
2018\end{array}$ & $\begin{array}{l}\text { Menilai efektivitas } \\
\text { Lavender cream dan } \\
\text { footbath pada kualitas } \\
\text { tidur saat hamil dan } \\
\text { post-partum. }\end{array}$ & $\begin{array}{l}\text { Randomized, } \\
\text { placebo- } \\
\text { controlled trial }\end{array}$ & $\begin{array}{l}141 \text { wanita hamil } \\
\text { usia kehamilan } 25 \\
\text { hingga } 28 \text { minggu } \\
\text { dan memiliki } \\
\text { Tidur Pittsburgh } \\
\text { Score Quality } \\
\text { Index } 5 \text { atau lebih } \\
\text { dari } 5\end{array}$ & $\begin{array}{l}\text { Skor global kualitas tidur pasca } \\
\text { intervensi pada kehamilan dan } \\
\text { postpartum adalah signifikansi } \\
\text { jauh lebih rendah di kelompok } \\
\text { Lavender dengan footbath maupun } \\
\text { kelompok yang tanpa footbath } \\
\text { (diberikan Lavender krim saja). } \\
\text { Penurunan skor PSQS sebesar 0,6 } \\
\text { untuk kelompok yang diberikan krim } \\
\text { lavender dan ditambah footbath, } \\
\text { sedangkan yang hanya diberikan krim } \\
\text { saja menurun sebanyak 1,3. }\end{array}$ & $\begin{array}{l}\text { Tujuannya sama yaitu menilai } \\
\text { efektifitas intervensi non farmakologi } \\
\text { untuk meningkatkan kualitas tidur } \\
\text { postpartum } \\
\text { Menggunakan kuesioner baku untuk } \\
\text { menilai hasil ukur kualitas tidurnya } \\
\text { Sama-sama menggunakan kriteria } \\
\text { inklusi wanita dengan persalinan } \\
\text { pervaginam }\end{array}$ & $\begin{array}{l}\text { Menggabungkan dua intervensi yaitu } \\
\text { pemberian krim lavender pada kaki } \\
\text { kemudian ditambah merendam kaki di air } \\
\text { bersuhu } 40-42^{\circ} \mathrm{C} \text {. Intervensi untuk menilai } \\
\text { kualitas tidur diberikan } 3 \text { titik waktu yaitu } 2 \\
\text { kali saat masa hamil dan } 1 \text { kali setelah } \\
\text { melahirkan. }\end{array}$ \\
\hline
\end{tabular}

